\title{
Shifting the Assessment Paradigm from Knowledge to Skills: Implementation of New Appraisal Procedures in EFL Classes in Uzbekistan
}

\author{
Shakhlo Sadullaeva, Yana Arustamyan, Nilufar Sadullaeva
}

\begin{abstract}
The present study is devoted to the analysis of the situation emerging in Uzbekistan classes teaching English as a foreign language on the level of higher education in connection with the modernization of assessment procedures. The research aims at defining the problems occurring in assessment systems, analysis of the reasons that lead to this situation, and suggestion of possible solution to them. In the course of experiment different approaches were suggested to the appraisal of knowledge, obtained as learning outcomes and skills, developed as a result of application of the acquired knowledge. The experimental design, basing on four principal stages of monitoring (informational, diagnostic, comparative, and prognostic) proved the inability of the students to employ higher cognitive skills in the process of finding solutions to the problems stated as revised test assignments.
\end{abstract}

Keywords: assessment, evaluation, EFL, monitoring, washback effect

\section{INTRODUCTION}

Assessment is an inseparable part of educational cycle, which do not only confirm the learning outcome, but also presents some other functions, like motivation for further improvement for students (Boud 2000; Fletcher et. all 2012) or promotion of redesigning the structure and materials of the course for teachers. These key moments should lay the foundation for the elaboration of proper assessment in Uzbekistan, because Uzbekistan inherited some traditions in educational sphere from Soviet times, being a country of former Soviet Union. We are not intended to criticize the whole Old Soviet school, though some of the problems still exist. The principal challenge is the issues connected with evaluation of study results that mostly need serious reconsideration from the very beginning, the goal of assessment, to the final point, which is the level of validity, reliability, and transparency of the assessment results. Nowadays, Uzbekistan is in a very high progress in all spheres, including economic, infrastructural, cultural, and social sides. The peculiar attention is paid to the reforms in education, especially the issues connected to the learning foreign languages. The sphere of learning languages is highly supported by the government as Uzbekistan is opened to the global society and speaking a foreign

Revised Manuscript Received on October 15, 2019.

Shakhlo Sadullaeva, DSc, Dean of the Faculty of "Vocational Education in the Field of ICT", Tashkent University of Information Technologies named after Muhammad al-Khwarizmi, Tashkent, Uzbekistan(Email: orif_sh@list.ru)

Yana Arustamyan, Associate professor, $\mathrm{PhD}$, Department of Comparative Linguistics, National University of Uzbekistan, Tashkent, Uzbekistan(Email: yana.arustamyan@yandex.com)

Nilufar Sadullaeva, Associate professor, $\mathrm{PhD}$, Tashkent, Uzbekistan language is an essential component of mutual understanding between countries. Therefore, in spite of the fact that many innovations, like new teaching methods, were introduced into the process of teaching and learning English, in particular, the assessment process still needs serious improvement. Two urgent problems are observed here within the learning English in higher educational establishments: the distinction of appraisal approaches to knowledge and skills, which results in lack of formative approaches to assessment process in EFL classes and scoring system itself. The importance of differentiating knowledge and skills was critically discussed in previous researches (Boruff and Harrison 2018, Bahar-Ozvaris et al. 2004). However, there are still some blank spots for the embedment of diversity in this direction concerning English language acquisition, because the variability of appraisal procedures may lead to the increase of effectiveness of the learning process on the whole (Race 2009; Ramsden 2003).

\section{PROPOSED METHODOLOGY}

Taking into consideration the specificity of teaching English process, it is very difficult to subdivide knowledge and skills one from another as initially it is impossible to develop language skills without knowledge component. However, some modern approaches to teaching languages, like communicative approach, assume developing practical language skills without paying much attention to learning theory, like grammar rules or lexical combination regulations. Such approaches are mostly based on Krashen's natural approach to second language acquisition (Krashen 1987, Krashen 1988) Consequently, developing this idea we should clarify the understanding of the concept knowledge applied in our research. Collins free online English dictionary presents the following definition: 'Knowledge is information and understanding about a subject which a person has, or which all people have'. While Dictionary by Merriam-Webster suggests more variable interpretations of this concept:

' $1 \mathrm{a}(1)$ : the fact or condition of knowing something with familiarity gained through experience or association; (2): acquaintance with or understanding of a science, art, or technique; $b(1)$ : the fact or condition of being aware of something; (2): the range of one's information or understanding; c: the circumstance or condition of 
apprehending truth or fact through reasoning ; d: the fact or condition of having information or of being learned; $2 \mathrm{a}$ : the sum of what is known : the body of truth, information, and principles acquired by humankind; $b$ archaic : a branch of learning'. webster.com/dictionary/knowledge)

Business Dictionary emphasizing the result of human thinking activity from the process of 'understanding that germinates from combination of data, information, experience, and individual interpretation... In an organizational context, knowledge is the sum of what is known and resides in the intelligence and the competence of people' supports the definition by philosophic views bringing the citations by prominent philosophers:

'Things that are held to be true in a given context and that drive us to action if there were no impediments' (Andre Boudreau); 'Capacity to act' (Karl Sweiby); 'Justified true belief that increases an entity's capacity for effective action (Nonaka and Takeuchi); 'The perception of the agreement or disagreement of two ideas' (John Locke). (http://www.businessdictionary.com/definition/knowledge.h tml)

Within the observation of these definitions, we can feature the similar interpretations comprising different meanings, from understanding the information to the application of it ("experience", "competence"). However, in our opinion, in the process of language acquisition the differentiation between knowledge and skills should be as it may influence on the approaches to assessment techniques. Therefore, the present research is based on the specification of knowledge as a scope of information, regularities, theories understood and remembered in the process of learning; while skills will be defined as a set of practical knacks or habits developed from the acquired knowledge, in other words, the ability to apply knowledge into real-life situations.

The National Standards for learning foreign languages were seriously redesigned after the Resolution PR-1875 "On the measures of further improvements of teaching foreign languages" adopted on December 10, 2012. This resolution gave a strong impetus to the reconsideration of the process of teaching and learning foreign languages on the whole. However, in spite of the multiple positive introductions of new teaching methods improving this process, the problem of assessment is still uncertain as some of the aspects of assessment procedures are still unclear or undeveloped properly. This fact inspired us to develop this issue as assessment is not only verification of learning outcomes (van de Watering et al. 2008) or challenge for further development, but also a very fundamental driving force from the assessment to learning (Khan, 2010). Nowadays it is a fact that assessment presents a vital component of any learning process, therefore, should be recognized as an integral part of a teaching process (van de Watering et al 2008; Brown et al. 1994; Gibbs 1999; Scouller 1998) Besides, new approaches to the understanding of assessment in its progress as differentiation of "assessment for learning" and "assessment as learning" (Sadler 1989; Marshall and Drummond 2006; Torrance 2007; Dann 2014) motivates us to reconsider the process of assessment procedure in Uzbekistan EFL classes.

\section{RESULTS \& DISCUSSIONS}

The conducted research was based primarily on the method of survey, which involved 20 teachers of the faculty of the Department of Comparative Linguistics at the National University of Uzbekistan and 350 students from the second, third, and fourth courses of the same department. We did not engage the first-year students as they were still not completely involved in all assessment procedures. During the experiment the teachers were asked to fill in the questionnaires and answer the questions aiming at revealing the situation with their deep understanding of the assessment process and procedures in connection with learning outcomes, redesigning instructions, motivation, and further improvement of the courses (Table 1). 
Table 1. Sample of the questionnaire for teachers

\begin{tabular}{|c|c|c|c|}
\hline & $\mathrm{A}$ & B & $\mathrm{C}$ \\
\hline $\begin{array}{lr}\text { Do you lecture or } \\
\text { conduct } & \text { practical } \\
\text { lessons? } & \end{array}$ & Lecture & Practical classes & Both \\
\hline $\begin{array}{l}\text { Are you satisfied with } \\
\text { the quality of assessment } \\
\text { procedures taken in your } \\
\text { classes? }\end{array}$ & Yes & No & Partly \\
\hline $\begin{array}{l}\text { Are you satisfied with } \\
\text { the scoring system } \\
\text { applied for evaluation? }\end{array}$ & Yes & No & Partly \\
\hline $\begin{array}{l}\text { Do you use both } \\
\text { formative and summative } \\
\text { type of assessment? }\end{array}$ & Yes & No & $\begin{array}{l}\text { I do not know about the } \\
\text { difference between these } \\
\text { two types }\end{array}$ \\
\hline $\begin{array}{l}\text { Which techniques and } \\
\text { activities do you use in } \\
\text { assessment procedures? }\end{array}$ & $\begin{array}{l}\text { Only MC tests and } \\
\text { essays }\end{array}$ & $\begin{array}{l}\text { Open ended test and oral } \\
\text { interview }\end{array}$ & $\begin{array}{l}\text { Others (please, name } \\
\text { particular techniques and } \\
\text { activities) }\end{array}$ \\
\hline $\begin{array}{l}\text { How often do you have } \\
\text { assessment procedure in } \\
\text { your classes? }\end{array}$ & $\begin{array}{l}4 \text { times per semester: } 2 \\
\text { current controls, } 1 \\
\text { interim control, } 1 \text { final } \\
\text { control }\end{array}$ & $\begin{array}{l}\text { Every lesson. At least } \\
\text { oral feedback is given }\end{array}$ & Depends on the course \\
\hline $\begin{array}{l}\text { Can the assessment } \\
\text { procedure influence on } \\
\text { the improvement of } \\
\text { learning? }\end{array}$ & $\begin{array}{l}\text { Yes, it is a good } \\
\text { motivation and stimulus } \\
\text { for further progress }\end{array}$ & $\begin{array}{l}\text { No, it only ascertains the } \\
\text { learning outcome }\end{array}$ & $\begin{array}{l}\text { I have never thought } \\
\text { about it }\end{array}$ \\
\hline $\begin{array}{l}\text { Can the assessment } \\
\text { procedure influence on } \\
\text { the improvement of } \\
\text { teaching? }\end{array}$ & $\begin{array}{l}\text { Yes, teachers may } \\
\text { reconsider their lesson } \\
\text { plans and content basing } \\
\text { on the results of } \\
\text { assessment }\end{array}$ & $\begin{array}{l}\text { No, assessment is a } \\
\text { procedure only for } \\
\text { students, not for teachers }\end{array}$ & $\begin{array}{l}\text { I have never thought } \\
\text { about it }\end{array}$ \\
\hline
\end{tabular}

The content of the questions was based on the traditional structure of summative assessment procedure in higher educational establishments in Uzbekistan on linguistic specialties: every course includes two types of current controls, one or two interim control/s, and final control. Total score is 100 points, of which $70 \%$ is given to current and interim control and $30 \%$ is taken during final control. If a student is not able to earn at least 39 point during current and interim controls, s/he will not be admitted to the final control. The procedure of final control is usually taken in written form and by at least two teachers in the classroom.

Taking into consideration the reasonable commentary suggested by Isaacs and Lamprianou (2018) who emphasized rare involvement of learners in policy decisions, the survey stage also included the students' responses to the questionnaire basing on the existent conditions of educational system. (Table 2)

Table 2. Sample of the questionnaire for students

\begin{tabular}{|c|c|c|c|}
\hline & $\mathrm{A}$ & $\mathrm{B}$ & $\mathrm{C}$ \\
\hline $\begin{array}{l}\text { Which course do you } \\
\text { study at? }\end{array}$ & 2 & 3 & 4 \\
\hline $\begin{array}{l}\text { Are you satisfied with the } \\
\text { assessment procedures } \\
\text { applied in your courses? }\end{array}$ & Yes & No & Sometimes \\
\hline $\begin{array}{l}\text { Do you feel any } \\
\text { difference } \\
\text { assessing knowledge and } \\
\text { skills? }\end{array}$ & Yes & No & $\begin{array}{l}\text { Do not see the difference } \\
\text { between knowledge and } \\
\text { skills }\end{array}$ \\
\hline $\begin{array}{l}\text { Can assessment motivate } \\
\text { you to study better? }\end{array}$ & Yes & No & $\begin{array}{l}\text { I have never thought } \\
\text { about it }\end{array}$ \\
\hline $\begin{array}{l}\text { Would you like to } \\
\text { improve the assessment } \\
\text { procedures in your } \\
\text { courses? }\end{array}$ & Yes & No & I don't care \\
\hline
\end{tabular}




\begin{tabular}{|l|l|l|l|}
\hline $\begin{array}{l}\text { What is your favorite way } \\
\text { of assessment? }\end{array}$ & Oral & Written & $\begin{array}{l}\text { I would prefer to have no } \\
\text { assessment at all }\end{array}$ \\
\hline $\begin{array}{l}\text { Do you think feedback is } \\
\text { important for you? }\end{array}$ & Yes & No & $\begin{array}{l}\text { Have never thought about } \\
\text { it }\end{array}$ \\
\hline
\end{tabular}

The subjects were sorted out as theoretical and practical courses. Theoretical disciplines included such subjects as The History of the English Language, Comparative Linguistics, Theoretical Grammar, Theoretical Phonetics, Country Studies, Linguistics, Theory of Translation. Among practical subjects were: Reading, Writing, Listening, and Speaking classes.

\section{APPROACH}

Supplementary methods were expert panel method (Nind \& Lewthwaite 2018), observation, statistical analysis, case studies. The expert panel method suggested by Nind \& Lewthwaite (2018) was slightly adapted to the local reality: the panel discussions were held in person every three weeks with the participation of selected experts in the sphere of EFL classes arguing the obtained results and further suggestions. Observations were taken during two periods of four months each (summer and winter sessions) which included the monitoring of progressive or regressive results from the point of controlling material learning acquisition (the level of knowledge) and mastering practical skills (the level of skills) including the effectiveness of both formative and summative assessment. The method of case studies was used to introduce the experimental techniques of assessment which were not used before at these university courses. The introduction of new assessment methods like "doing it" exam, essay plans, or field reports allowed teachers to control development of English-speaking skills in certain spheres of science or technology. The method of multiplechoice questions was also improved by the reconsideration of questions with accent shift from knowledge-check into practical application skills. In the process of analysis, the washback effect was also considered as it 'refers to the extent to which the introduction and use of a test influences language teachers and learners to do things they would not otherwise do that promote or inhibit language learning' (Messick 1996, p. 241). As it was revealed, the problem of washback effect was not seriously taken into consideration during EFL classes assessment before.

Concerning the ways of monitoring, the following methods, basing on the methodology presented by Zvonnikov and Chelishkova (2013), were applied:

Informational monitoring, which included collection, accumulation, analysis, structuring, and interpretation of the data basing on the stating character, but not on the prognostic basis.

- Diagnostic monitoring, aiming at definition of the level of acquisition of learning materials in accordance with curricula and syllabi recommended for certain course for each specialty.

- $\quad$ Comparative monitoring, which was defined by a specific data analysis including the quantitative comparison of results obtained during the assessment procedures.

- $\quad$ Prognostic monitoring, intended for revelation and assumptions of both positive and negative tendencies in the development of assessment tasks and procedures.

The conducted analysis proved the main concern of the authors about existed problems in assessment system of EFL classes in Uzbekistan tertiary education. The primary solicitude was connected to the way of appraisal and teachers' indifference to the application of formative assessment as well as different approaches to evaluation of knowledge and skills. According to the collected data, only $10 \%$ of teachers at the Department of Comparative Linguistics use formative assessment in their EFL classes, while the majority (80\%) either do not know about this type of assessment procedure or use it somehow without paying attention to its importance. (Figure 1) Here we should again emphasize that formative assessment is not traditionally or widely used in EFL classes in Uzbekistan higher educational establishments. The principle form of evaluation students' knowledge (mostly) and skills (less) is summative assessment that influence on the attestation and finally on the administrative admission for further continuation of the study, obtaining scholarship or diploma. 


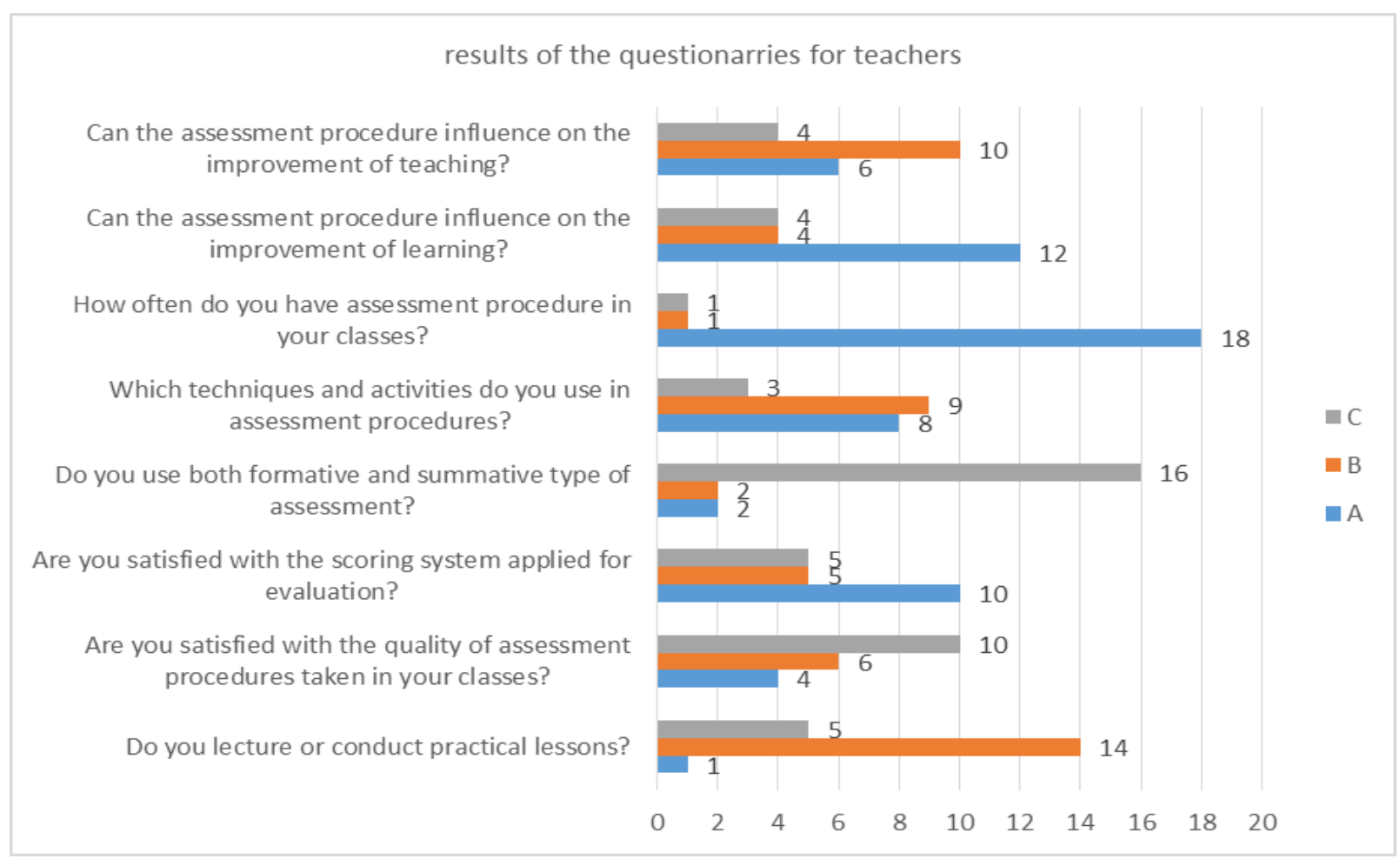

Figure 1. Results of the questionnaires for teachers.

Another moment that also concerns us in this situation is that most teachers are not completely satisfied with the forms, methods, or ways of assessment procedures they embed in their classes. The survey illustrates rather high level of teachers who want to change the situation. After several workshops presented by the leading experts and panel discussions the majority of teachers were inspired by the implication of new methods of appraisal techniques, as well as the evaluation of the assignments as well. Moreover, the experiment revealed the necessity of differentiating the approaches to assessment of knowledge and skills, because standard multiple choice questions did not satisfy the appraisal of the level of application of obtained knowledge. On the other hand, the elaboration of the tests used in practice corroborated the effectiveness of MCQ-tests, however, they should be created with the shifted accent: from knowledge to skills. For example:

Standard test (ST)

Revised test (RT)

Amelioration is ...

a) a process through which one sound becomes more like another in its environment

b) the term used when a word "rises" in its linguistic or social status c) occurs only sporadically in individual words

Find the example of amelioration in the following lines:

a) silly: 'blessed' $\rightarrow$ 'clean, simple' $\rightarrow$ 'stupid' b) queen: 'woman' $\rightarrow$ 'noble woman' $\rightarrow$ 'female monarch' c) help: 'holp' $\rightarrow$ 'holpen' $\rightarrow$ 'helped'
The first column illustrates the "knowledge-test", where the students need mostly rote learning. In other words, this type covers cognitive domain including such levels as understanding and, mostly, remembering. However, it does not reflect the degree of analysis or application referring to the development of higher cognitive skills. Therefore, the main goal of assessing mastered skills can be checked through the questions which refer to the evaluation, analysis, and application, according to the Bloom's Taxonomy (Bloom, 1956). In this way, the question from the second column demonstrates the necessity of understanding the core of the term and ability to apply it in practice. Such revision helped the teachers to reconsider their tasks and develop the MCQ tasks based on the appraisal of skills, not only knowledge.

On the other hand, the other side of the experiment, the students, were also not ready for the embedment of new types of assessment. (Figure 2) 
Shifting the Assessment Paradigm from Knowledge to Skills: Implementation of New Appraisal Procedures in EFL Classes in Uzbekistan

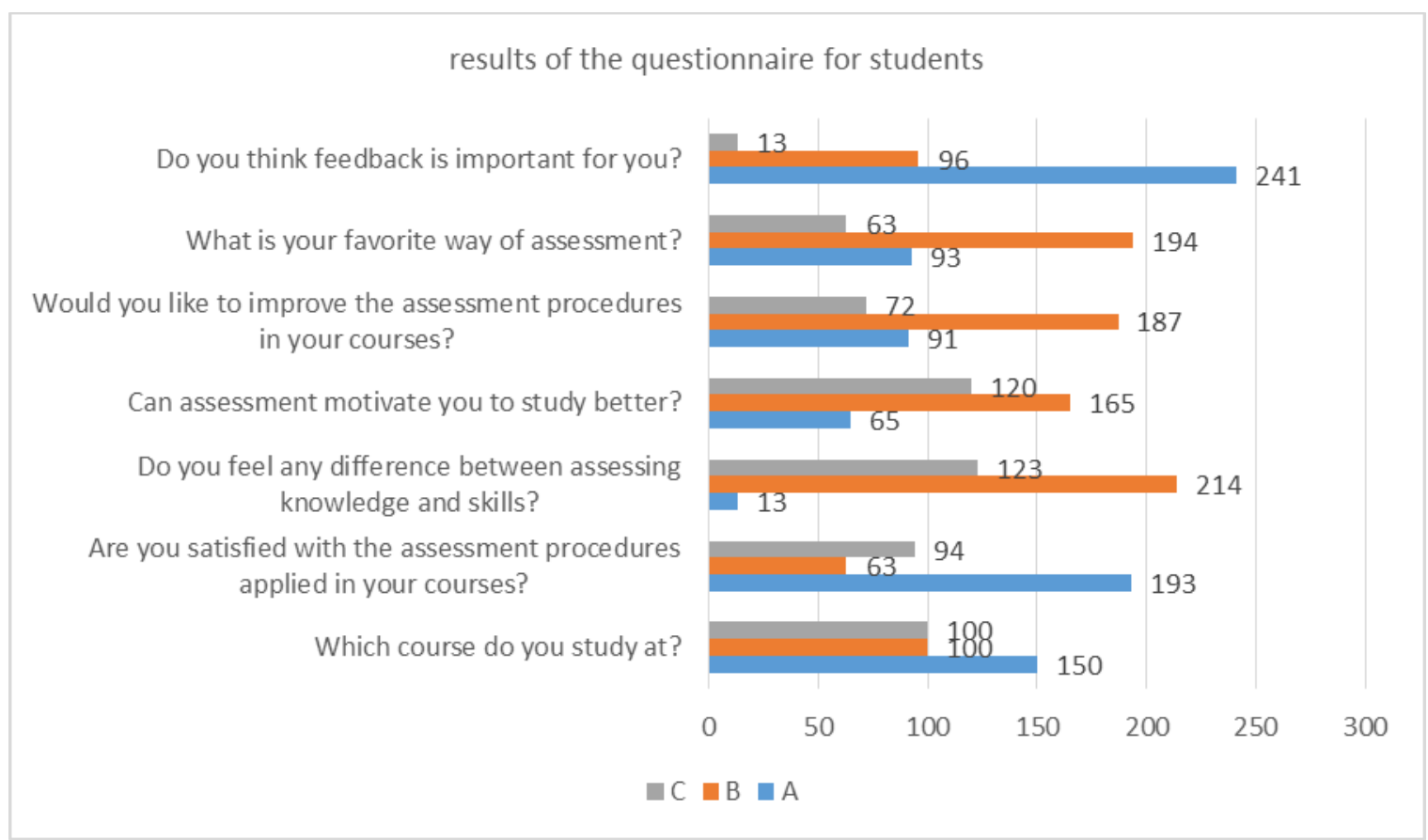

Figure 2. Results of the questionnaires for students.

Besides, according to the informational monitoring, have never thought about the importance of the assessment, or, using the terminology of Marshall and Drummond (2006) assessment for learning or, according to the terminology by Dann (2014) assessment as learning. However, the conducted survey showed that most of the students consider the role of feedback to be important, which certainly proves the fact that assessment results may influence on their understanding of the efficiency of assessment as an integrated part of learning process on the whole.
The third stage of the conducted experiment included the comparison of the results taken with standard procedure and experimental tasks. The analysis showed that on some theoretical subjects students were not ready to apply their knowledge: having answered rather well on the "knowledgetest" (ST), some of them failed the "skills-diagnostic test"(RT). The lowest passing rate was observed at the courses "The History of the English Language", "Comparative Typology", and "Theoretical Grammar of the English Language”. (Table 3)

Table 3. Comparative results of traditional and experimental assignments

\begin{tabular}{|c|c|c|c|c|c|c|c|c|c|}
\hline \multirow[t]{2}{*}{ Subject } & \multirow[t]{2}{*}{$\begin{array}{l}\text { Number of } \\
\text { students }\end{array}$} & \multirow[t]{2}{*}{$\begin{array}{l}\mathrm{ST} \\
(\%)\end{array}$} & \multirow[t]{2}{*}{$\begin{array}{l}\mathrm{RT} \\
(\%)\end{array}$} & \multicolumn{2}{|c|}{$\begin{array}{l}\text { Highest } \\
\text { passing rate } \\
(\%)\end{array}$} & \multicolumn{2}{|c|}{$\begin{array}{l}\text { Lowest } \\
\text { passing rate } \\
(\%)\end{array}$} & \multicolumn{2}{|c|}{ p-value } \\
\hline & & & & ST & RT & ST & RT & ST & RT \\
\hline \multicolumn{10}{|c|}{ Theoretical courses } \\
\hline $\begin{array}{l}\text { Theory of } \\
\text { translation }\end{array}$ & 100 & 96 & 81 & 98 & 86 & 55 & 42 & 0.78 & 0.66 \\
\hline $\begin{array}{l}\text { Comparative } \\
\text { typology }\end{array}$ & 100 & 73 & 38 & 86 & 52 & 44 & 18 & 0.68 & 0.28 \\
\hline $\begin{array}{l}\text { Theoretical } \\
\text { grammar }\end{array}$ & 100 & 88 & 36 & 90 & 62 & 48 & 16 & 0.65 & 0.32 \\
\hline $\begin{array}{l}\text { History of the } \\
\text { English } \\
\text { language }\end{array}$ & 100 & 80 & 42 & 86 & 62 & 54 & 22 & 0.46 & 0.34 \\
\hline $\begin{array}{l}\text { Theoretical } \\
\text { phonetics }\end{array}$ & 100 & 83 & 76 & 88 & 78 & 62 & 55 & 0.72 & 0.64 \\
\hline Country study & 150 & 90 & 86 & 92 & 88 & 68 & 76 & 0.72 & 0.54 \\
\hline Linguistics & 150 & 78 & 63 & 82 & 66 & 68 & 54 & 0.60 & 0.42 \\
\hline \multicolumn{10}{|c|}{ Practical disciplines } \\
\hline Listening & 350 & 78 & 72 & 86 & 80 & 56 & 48 & 0.72 & 0.56 \\
\hline Reading & 350 & 80 & 64 & 82 & 76 & 55 & 42 & 0.66 & 0.42 \\
\hline Writing & 350 & 86 & 72 & 90 & 76 & 56 & 40 & 0.48 & 0.32 \\
\hline Speaking & 350 & 90 & 86 & 92 & 90 & 56 & 42 & - & \\
\hline
\end{tabular}


In comparison with the practical disciplines, which are aimed at developing practical language skills, the situation was much better: it proves the fact that practical disciplines are more skills-developing oriented. In this concern we must emphasize once again the importance of correlation between theory and its implication into real-life situations that claims for the reconsiderations of lesson plans and teaching methods, clarification and specification of learning objectives, and revising the materials of the courses. However, the main result of the conducted experiment highlights an urgent necessity to change educational paradigm basing on the new effective approaches to assessment.

Concerning the practical disciplines, the situation was more encouraging. Initially, the assignments were composed more skill-oriented, however, the reading tasks firstly were more aimed at checking the levels of understanding and remembering the meaning of the words without consideration of their contextual meaning from both lexical and grammar point of view. The average passing score of the revised tasks made up $64 \%$ in comparison with $80 \%$ of the standard test which illustrate the fact that students may not be ready to apply their knowledge of the meanings of some words within the frames of either combinability or situational synonymy. The revised tasks presented the tests with the estimation of contextual meaning and lexicalgrammatical combinability. Here we agree with the statement by Frankenberg-Garcia (2018) that 'lexical knowledge is not about understanding words, but also about employing words in context' (p. 101).

The following prognostic stage assumed the analysis of advantages and drawbacks of the applied assignments succeeded by experimental tasks. According to the results obtained at the previous stage, not all the tasks were successfully applied in the course of the experiment, though they helped to reveal serious problems in the process of preparation as well as lecturing and served as a stimulus for reconsideration of learning procedures on the whole. After several panel discussions with experts as well as students' opinion poll, the most appropriate types of appraisal assignment were agreed as MCQ (4 options, with p-value .62), concept maps, problem sheets (Table 4).

Table 4. Comparison of assessment methods' results in theoretical courses

\begin{tabular}{|c|c|c|c|c|}
\hline Method & Recommended discipline & $\begin{array}{l}\text { Teachers' } \\
\text { preferences } \\
(\%)\end{array}$ & $\begin{array}{l}\text { Students' } \\
\text { preferences } \\
(\%)\end{array}$ & $\begin{array}{l}\text { Efficiency } \\
(\%)\end{array}$ \\
\hline \multicolumn{5}{|l|}{ Theoretical courses } \\
\hline \multirow[t]{5}{*}{ MCQ } & Comparative Typology & \multirow[t]{5}{*}{82} & \multirow[t]{5}{*}{91} & 62 \\
\hline & Theoretical Grammar & & & 86 \\
\hline & Theoretical Phonetics & & & 88 \\
\hline & Country Study & & & 72 \\
\hline & History of the English Language & & & 68 \\
\hline \multirow[t]{5}{*}{ Concept Map } & Theory of Translation & \multirow[t]{5}{*}{92} & \multirow[t]{5}{*}{84} & 78 \\
\hline & Theoretical Grammar & & & 82 \\
\hline & Theoretical Phonetics & & & 80 \\
\hline & Linguistics & & & 76 \\
\hline & Comparative Typology & & & 86 \\
\hline \multirow[t]{3}{*}{ Problem Sheet } & Comparative Typology & \multirow[t]{3}{*}{90} & \multirow[t]{3}{*}{78} & 76 \\
\hline & Linguistics & & & 72 \\
\hline & Theory of Translation & & & 80 \\
\hline \multirow[t]{7}{*}{ Discussion } & Comparative Typology & \multirow[t]{7}{*}{92} & \multirow[t]{7}{*}{62} & 38 \\
\hline & Theoretical Grammar & & & 80 \\
\hline & Theoretical Phonetics & & & 72 \\
\hline & History of the English Language & & & 32 \\
\hline & Country Study & & & 68 \\
\hline & Linguistics & & & 44 \\
\hline & Theory of Translation & & & 76 \\
\hline \multirow[t]{4}{*}{ Short Answer Question } & Theoretical Grammar & \multirow[t]{4}{*}{86} & \multirow[t]{4}{*}{73} & 82 \\
\hline & Theoretical Phonetics & & & 76 \\
\hline & History of the English Language & & & 48 \\
\hline & Linguistics & & & 53 \\
\hline \multirow[t]{2}{*}{ Seen exams } & Comparative Typology & \multirow[t]{2}{*}{78} & \multirow[t]{2}{*}{70} & 63 \\
\hline & Theoretical Grammar & & & 76 \\
\hline
\end{tabular}


Shifting the Assessment Paradigm from Knowledge to Skills: Implementation of New Appraisal Procedures in EFL Classes in Uzbekistan

\begin{tabular}{|c|c|c|c|c|}
\hline & Theoretical Phonetics & & & 72 \\
\hline & History of the English Language & & & 80 \\
\hline & Country Study & & & 86 \\
\hline & Linguistics & & & 68 \\
\hline & Theory of Translation & & & 86 \\
\hline \multirow{3}{*}{$\begin{array}{ll}\begin{array}{l}\text { Designing } \\
\text { materials }\end{array} & \text { learning } \\
\end{array}$} & Theory of Translation & \multirow[t]{3}{*}{82} & \multirow[t]{3}{*}{60} & 90 \\
\hline & History of the English Language & & & 78 \\
\hline & Country Studies & & & 80 \\
\hline
\end{tabular}

The most perspective assessment procedures for practical disciplines were recognized case studies, essays/essay plans,

type of assessment methods was also mostly preferred by open-ended questions, presentations, portfolio. The same the students (Table 5).

Table 5. Comparison of assessment methods' results in practical disciplines

\begin{tabular}{|c|c|c|c|c|}
\hline Method & $\begin{array}{l}\text { Recommended } \\
\text { discipline }\end{array}$ & $\begin{array}{l}\text { Teachers' } \\
\text { preferences }(\%)\end{array}$ & $\begin{array}{l}\text { Students' } \\
\text { preferences }(\%)\end{array}$ & Efficiency (\%) \\
\hline \multicolumn{5}{|l|}{ Practical disciplines } \\
\hline \multirow[t]{2}{*}{ Case studies } & Writing & \multirow[t]{2}{*}{90} & \multirow[t]{2}{*}{82} & 82 \\
\hline & Speaking & & & 84 \\
\hline Essays & Writing & 74 & 78 & 86 \\
\hline Essay plans & Writing & 82 & 84 & 80 \\
\hline \multirow[t]{4}{*}{ Open-ended questions } & Listening & \multirow[t]{4}{*}{94} & \multirow[t]{4}{*}{76} & 64 \\
\hline & Speaking & & & 78 \\
\hline & Writing & & & 76 \\
\hline & Reading & & & 82 \\
\hline Presentations & Speaking & 94 & 88 & 82 \\
\hline \multirow[t]{2}{*}{ Portfolio } & Writing & \multirow[t]{2}{*}{87} & \multirow[t]{2}{*}{73} & 86 \\
\hline & Speaking & & & 88 \\
\hline \multirow{4}{*}{$\begin{array}{l}\text { Designing learning } \\
\text { materials }\end{array}$} & Listening & \multirow[t]{4}{*}{83} & \multirow[t]{4}{*}{56} & 73 \\
\hline & Speaking & & & 78 \\
\hline & Writing & & & 60 \\
\hline & Reading & & & 58 \\
\hline Discussion & Speaking & 96 & 42 & 80 \\
\hline \multirow[t]{4}{*}{ Exit slips } & Listening & \multirow[t]{4}{*}{94} & \multirow[t]{4}{*}{57} & 38 \\
\hline & Speaking & & & 87 \\
\hline & Writing & & & 64 \\
\hline & Reading & & & 71 \\
\hline
\end{tabular}

The students' assessment preferences (van de Watering 2008) were also analyzed here, though at this stage the correlation between preferences and perception was not ostensible. The explanation also lies within the necessity of changing the attitude towards assessment procedures on the whole from both teachers' and students' perspectives.

\section{ANALYSIS}

However, the obtained results illustrate a significant positive correlation between the level of efficiency and teachers' and students' preferences in the choice of assessment method. Moreover, accessory goal of the experiment was achieved: the students' attitude to the assessment procedure was changed from ordinary scoring procedure reflected by the summative assessment into comprehension of formative assessment and its side functions, like motivation and differentiation between improvement of knowledge and developing skills.

In this concern the washback effect was also evaluated. Having analyzed the highest and lowest passing rates several conclusions were made:

- Theoretical disciplines aiming at developing knowledge and, therefore, mostly using testing practice as an assessment tool need serious reconsideration in both direction: changing of assessment procedures and developing of the skills, which help students to apply the knowledge into solution to real-life tasks.

- $\quad$ Learning objectives need to be revised and shifted to developing higher cognitive skills.

- $\quad$ The materials for practical disciplines may be more skills-oriented: students should be able to identify the contextual meaning of the words and word-combinations from both grammar and lexical point of view, in other words, they need master their skills on the level of synthesis, application, and creation/ 
- The assessment procedures must be clarified in recommendations given in the National Standards for learning foreign languages reflecting the objectives of each disciplined stated in the curricula.

During the recent years the educational paradigm in the sphere of learning foreign languages in Uzbekistan has changed seriously. However, despite multiple innovative technologies introduced in this sphere some urgent problems still exist. The major challenge here is assessment procedures which have many blank spots in both directions: the procedure itself (including the variety of assignments and tasks, introduction of different approaches to evaluation of knowledge and skills, psychometric parameters of tasks) and the functions of assessment (formative types of assessment aiming at monitoring, motivating, and improving learning outcomes). We do not strongly assert that there is no understanding of formative assessment procedures in Uzbekistan: there are a number of researches done in this field (Radjabova 2018; Author 2018; Toshpulatova 2015). Nevertheless, traditional approaches do not mostly engage this type or pay insufficient attention to it.

\section{CONCLUSION}

According to the obtained results, the following picture was displayed: the students, as well as some teachers, were not ready to introduced changes. Having successfully passed through standard test evaluating the level of learned material (dealing with the levels of understanding and remembering), it was a serious concern for them to apply this knowledge into practice effecting on the higher cognitive levels. The other side of this problem was presented by the teachers who could not completely understand the correlation between appraisal of knowledge and skills as well as their developing in the courses and in this way having their students be ready to such kind of assessment procedures. In other words, the deepening of learning procedures with emphasizing the practical skills developed in each section may produce better results illustrating the ability of students apply their knowledge into practice. Therefore, a serious reconsideration of the existing assessment procedures, as well as the assignments themselves should be undertaken in EFL classes in higher educational establishments in Uzbekistan.

Besides, the washback effect is not still discussed widely, though it logically leads to the defining the problems of test validity in terms of social impacts of test application as well as the significance of correct interpretation of the test results (Brown, 2002). Moreover, according to Brown (2002) 'Washback, whether it is positive or negative, can be a potential boon or threat to language teaching curriculum (broadly defined) because, through washback, a test can steer a curriculum in one direction or another (in terms of teaching, course content, course characteristics, and/or class time) either with or against the better judgment of the administrators, teachers, students, parents, etc.' (p.11) Some researches also consider washback effect as an inseparable part of test-validity suggesting the term "washback validity" (Morrow 1986). Present research displayed the serious positive washback effect as a result of applied procedures. Undoubtedly, the conclusions that were made may serve as a basis for reconsideration of not only each subject included into curriculum, but also for the revision of the approaches to assessment in EFL classes on the whole. However, the washback effect was not the principal or even the minor goal of this study. That is the factor that should also be included into the analysis of the assessment environment in Uzbekistan higher educational establishments, which may be further developed in other researches.

\section{ACKNOWLEDGEMENTS}

The authors express their deep gratitude to all reviewers whose corrections and constructive notes improved the quality of the present article. We also gratefully acknowledge the Ministry of Innovative Development of the Republic of Uzbekistan for grant PZ-201709134 "Modern approaches to forms and principles of assessment the quality of learning English on philological specialities" within the framework of which the present research was conducted.

\section{REFERENCES}

1. Bahar-Ozvaris, S, Sonmez, R, Sayek, I. (2004) Assessment of knowledge and skills in primary health care services: senior medical students' self-evaluation. Teaching and learning in medicine 16(1), 34-38.

2. Biggs, J. B (2003). Teaching for quality learning at university: what the student does. 2nd ed. Buckingham: Society for Research into Higher Education

3. Bloom, B. (1956). Taxonomy of Educational Objectives: the Classification of Educational Goals. Susan Fauer Company

4. Bloxham, S., Boyd, P. (2007). Developing Effective Assessment in Higher Education - A Practical Guide. Maidenhead: McGraw-Hill.

5. Boruff, J.T., Harrison P. (2018). Assessment of knowledge and skills in information literacy instruction for rehabilitation sciences students: a scoping review. Journal of the Medical Library Association, http://doi.org/10.5195/jmla.2018.227.

6. Brown, J. D. (2002). Extraneous variables and the washback effect. Shiken: JALT Testing \& Evaluation SIG Newsletter, 6 (2), 10-13.

7. Brown, S., Rust, C., Gibbs, G. (1994). Strategies for diversifying assessment in higher education. Oxford: The Oxford Centre for Staff and Learning Development, Oxford Brookes University.

8. Boud, D. (2000). Sustainable assessment: Rethinking assessment for the learning society. Studies in Continuing Education, 22(2),151-167.

9. Business Dictionary. Retrieved from http://www.businessdictionary.com/definition/knowledge .html

10. Collins free online English dictionary. Retrieved from https://www.collinsdictionary.com/dictionary/english/kn owledge

11. Dann, R. (2014). Assessment as learning: blurring the boundaries of assessment and learning for theory, policy and practice. Assessment in Education: Principles, Policy \& Practice, 21(2), 149-166, 
http://doi.org/10.1080/0969594X.2014.898128.

12. Dictionary by Merriam-Webster. Retrieved from https://www.merriam-webster.com/dictionary/knowledge

13. Fletcher, R.B., Meyer, L.H., Anderson, H. et al. (2012). Faculty and Students Conceptions of Assessment in Higher Education. Higher Education, 64 (1), 119-133, https://doi.org/10.1007/s10734-011-9484-1.

14. Frankenberg-Garcia, A. (2018) Investigating the collocations available to EAP writers. Journal of English for Academic Purposes 35, 93-104 https://doi.org/10.1016/j.jeap.2018.07.003 1475-1585/

15. Gibbs, G. (1999). Using assessment strategically to change the way students learn. In S. Brown \& A. Glasner (Eds.), Assessment matters in higher education: Choosing and using diverse approaches ( $\mathrm{pp}$ 41-53). Buckingham: SRHE and Open University Press.

16. Isaacs, T., Lamprianou, I. (2018). International assessment policy reform: nothing new under the sun. Assessment in Education: Principles, Policy \& Practice, 25(3,) 227-229, http://doi.org/10.1080/0969594X.2018.1482094.

17. Khan, J.S. (2010). Assessment driven integrated learning (ADIL): assessment directed medical education (ADME) curriculum. J Ayub Med Coll Abbottabad, 22(4), 201206.

18. Krashen, S. D. (1987). Principles and Practice in Second Language Acquisition. Prentice-Hall International.

19. Krashen, S. D. (1988). Second Language Acquisition and Second Language Learning. Prentice-Hall International.

20. Marshall, B., Drummond, M. J. (2006). How teachers engage with Assessment for Learning: Lessons from the classroom. Research Papers in Education, 21, 133-149.

21. McCoubrie, P. (2004). Improving the fairness of multiple-choice questions: a literature review, Medical Teacher, 26(8), 709-712, http://doi.org/10.1080/01421590400013495.

22. Messick, S. (1996). Validity and washback in language testing. Language Testing, 13, 241-256.

23. Morrow, K. (1986). The evaluation of tests of communicative performance. Innovations in Language Testing. London: NFER/Nelson.

24. Nind, M., Lewthwaite, S. (2018) Methods that teach: developing pedagogic research methods, developing pedagogy. International Journal of Research \& Method in Education, 41(4), 398-410, http://doi.org/10.1080/1743727X.2018.1427057.

25. Race, P. (2009). UK Centre for Bioscience Briefing on Assessment. Leeds: HEA Centre for Bioscience.

26. Radjabova, G.G. (2018). The role of assessment in teaching English. O'zbekistonda horijiy tillar, 3(22), 9398.

27. Ramsden, P. (2003). Learning to Teach in Higher Education, 2nd edition. London: RoutledgeFalmer

28. Resolution PR-1875 On the measures of further improvements of teaching foreign languages. (2012). Retrieved from http://www.lex.uz/docs/2126032

29. Sadler, R. (1989). Formative assessment and the design of instructional systems. Instructional Science, 18, 119144.

30. Sadler, R. (1998). Formative assessment: Revisiting the territory. Assessment in Education: Principles, Policy \& Practice, 5, 77.

31. Scouller, K. (1998). 'The influence of assessment method on students' learning approaches: Multiple choice question examination versus assignment essay. Higher Education, 35, 453-472.

32. Torrance, H. (2007). Assessment as learning? How the use of explicit learning objectives, assessment criteria and feedback in post-secondary education and training can come to dominate learning. Assessment in Education. Principles, Policy \& Practice, 14, 281-294.
33. Toshpulatova, D. (2015). Forms and principles of assessment in teaching foreign languages. O'zbekistonda horijiy tillar, 7, 91-96.

34. Van de Watering, G., Gijbels, D., Dochy, F., Van der Rijt, J. (2008). Students' assessment preferences, perceptions of assessment and their relationships to study results. Higher Education, 56(6), 645. https://doi.org/10.1007/s10734-008-9116-6

35. Zvonnikov, V.I., Chelishkova, M.B. (2013) Современные средства оценивания результатов обучения [Modern means of assessment of learning outcomes]. Moskow: Academia. 